\title{
Anti-Scl-70 antibodies detected by immunoblotting
in progressive systemic sclerosis: specificity and clinical correlations
}

\author{
A AESCHLIMANN, ${ }^{1}$ O MEYER ${ }^{2}$ P BOURGEOIS, ${ }^{1}$ T HAIM ${ }^{2}$ \\ N BELMATOUG, 1 E PALAZZO,' AND M F KAHN
}

From the ${ }^{1}$ Clinique de Rhumatologie, Université Paris VII, Hôpital Bichat, Paris and the ${ }^{2}$ Laboratoireू d'Immuno-Rhumatologie, Hôpital Lariboisière, Paris

SUMMARY One hundred and forty five serum samples from patients with a connective tissuev disease and 30 serum samples from healthy blood donors were analysed by immunoblotting. Thee presence of anti-Scl-70, which seems to discriminate between progressive systemic sclerosis (PSS) and the CREST (calcinosis, Raynaud's phenomenon, oesophageal dysmotility, sclerodactyly, telangiectasia) syndrome, was found in 31/64 (48\%) patients with PSS, in $6 / 55(11 \%)$ patients

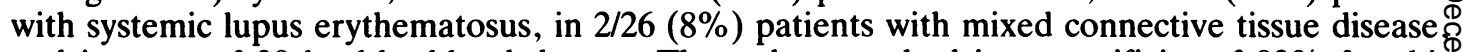
and in none of 30 healthy blood donors. These data resulted in a specificity of $93 \%$ for this antibody in systemic sclerosis. For patients with PSS the duration of disease was significantly shorter in those with anti-Scl-70 antibodies than in those without, whereas the presence $8 \hat{\varepsilon}$ anti-Scl-70 did not correlate with severity of disease. An $82 \%$ prevalence of anticentrom antibodies in patients with the CREST variant compared with a $4 \%$ prevalence in patients wibiti PSS or with overlap syndrome confirms the high diagnostic value of this autoantibody for the CREST variant of PSS.

Progressive systemic sclerosis (PSS) has been defined as 'a generalised disorder of small arteries, microvessels, and the diffuse connective tissue, characterised by scarring (fibrosis) and vascular obliteration in the skin, gastrointestinal tract, lungs, heart, and kidneys, in which hidebound skin is the clinical hallmark, and organ compromise the prognostic keystone'.

Various autoantibodies reacting with nuclear components may be present in the sera of patients with scleroderma. Antibodies that precipitate a soluble 70000 dalton nuclear protein called $\mathrm{Scl}-70,{ }^{2}$ identified recently as topoisomerase $I,{ }^{3}$ and antibodies directed against the centromere region of chromosomes have been reported to characterise respectively diffuse systemic sclerosis ${ }^{45}$ and the CREST variant of systemic sclerosis. ${ }^{6}$ Antibodies to Scl-70, which are considered almost specific for PSS and are also called $\mathrm{Scl}-86,{ }^{7}$ are found in only up to

Accepted for publication 7 March 1989.

Correspondence to Dr O Meyer. Clinique de Rhumatologie. Université de Paris. Hôpital Bichat. 46 rue Henri-Huchard, 75018 Paris, France.
$20 \%$ of patients with diffuse $\operatorname{PSS}^{45}$ and therefore $\overrightarrow{\overrightarrow{0}}$ are of limited diagnostic value using standardb techniques. Anticentromere antibodies, however: are present in $44-98 \%$ of patients with the CREST syndrome $^{68}$ as opposed to only $6-12 \%$ in PSS. ${ }^{5} 6$

These data were obtained in studies using routines techniques such as counterimmunoelectrophoresiš or immunodiffusion. In the past decade detection of antinuclear antibodies by immunoblotting was introduced. ${ }^{10}$

The purpose of our study was to analyse the different antinuclear antibodies in a group of 642 patients with PSS from a single centre, to compare the results obtained with different methods, such as immunodiffusion and immunoblotting, for anti $N$ nuclear antibody determination, and to define the specificity and sensitivity of these autoantibodies and their correlation with the clinical features.

\section{Patients and methods}

The study was performed retrospectively. We considered 64 patients with PSS who attended our 
centre between 1985 and 1987 and for whom serum samples were available. They were classified into three types according to Barnett and Coventry. ${ }^{11}$ Type I comprised patients with sclerodactyly $(n=15)$, type II those with skin changes involving hands, forearms, face, and neck $(n=13)$, and type III those in whom the skin changes were diffuse and usually most marked on the trunk $(n=7)$. Forty nine of 63 $(78 \%)$ patients fulfilled the recent criteria of the American Rheumatism Association (ARA) for diagnosis of PSS. ${ }^{12}$

Patients with the CREST variant of the disease ${ }^{6}$ were identified in a separate group $(n=11)$ as were patients with PSS with features of overlap syndrome $(n=18)$. Our CREST population was characterised by the prominence of calcinosis, Raynaud's phenomenon, sclerodactyly, telangiectasia, associated in two patients with oesophageal dysfunction.

The case reports were reviewed for sex, age, clinical manifestations, available laboratory and immunological data, histological and radiological documents, treatment, and outcome.

The control population consisted of 55 patients with systemic lupus erythematosus (SLE), who fulfilled at least four of the ARA 1982 revised criteria for the classification of SLE,$^{13} 26$ patients with mixed connective tissue disease (MCTD) according to the Alarcon-Segovia classification, ${ }^{14}$ and 30 healthy blood donors.

\section{STANDARD TECHNIQUES}

Serum samples were collected at the time of clinical examination, stored at $-20^{\circ} \mathrm{C}$ until use, and analysed without knowledge of the clinical data, together with the serum from control groups and healthy blood donors.

\section{Immunofluorescence}

Antinuclear antibodies were detected by indirect immunofluorescence on two different substrates: unfixed rat liver sections and acetone treated $\mathrm{HEp}_{2}$ cell preparations. In each case the conjugate used was a fluorescein labelled polyvalent antihuman immunoglobulin raised in goats. ${ }^{15}$

\section{Immunodiffusion}

Antibodies to extractable nuclear antigen were assayed by double immunodiffusion in agarose using the Ouchterlony technique against saline soluble antigens either from fresh calf thymus extract (U1RNP, Sm, SSB/La) or from human spleen extract (SSA/Ro). ${ }^{16}$ The extract of rabbit thymus powder (Pel-Freez, Rogers Arkansas, USA) used as the source of Scl-70 was made fresh as the Scl-70 antigen is labile. The precipitating reaction was read after a three day incubation at $6^{\circ} \mathrm{C}$ in a humid atmosphere and compared with an anti-Scl-70 reference serum.

\section{Immunoblotting}

For blotting analyses a total nuclear protein fraction from HeLa cells was prepared. ${ }^{17}$ Protein samples were dissolved in $2 \%$ sodium dodecyl sulphate, $10 \%$ glycerol, $5 \% \beta$-mercaptoethanol, $0 \cdot 1 \mathrm{M}$ TRIS $\mathrm{HCl}$ pH 6.8. Samples were heated for three minutes at $100^{\circ} \mathrm{C}$ followed by electrophoresis on $12 \%$ polyacrylamide gels. Proteins were loaded over the entire width of the gel and separated according to their molecular weight. ${ }^{18}$ After an 18 hour run at $50 \mathrm{~mA}$ per gel $(50 \mathrm{~V} / \mathrm{cm})$ replicas of the gels were made in nitrocellulose by transferring the proteins electrophoretically using a Bio-Rad trans blot system. Transfer was performed for four hours at $40 \mathrm{~mA}(80$ $\mathrm{V} / \mathrm{cm}$ ) and at $25^{\circ} \mathrm{C}$ in $192 \mathrm{mM}$ glycerol, $25 \mathrm{mM}$ TRIS pH $8 \cdot 3$, and $20 \%$ methanol. ${ }^{10}$ The protein blots were cut into strips of about $6 \mathrm{~mm}$ and treated with preincubation buffer $(3 \%$ bovine serum albumin, $10 \mathrm{mM} \mathrm{NaCl}$, TRIS $\mathrm{HCl} \mathrm{pH} \mathrm{7.6,0.5} \mathrm{mM} \mathrm{phenyl-}$ methylsulphonyl fluoride (PMSF)) for two hours at room temperature under constant agitation to saturate protein binding sites on the nitrocellulose.

Incubation with diluted patient's serum $(1 / 20)$ was performed for two hours in the following buffer: $0.3 \%$ bovine serum albumin, $150 \mathrm{mM} \mathrm{NaCl}, 10 \mathrm{mM}$ TRIS HCl pH 7.6, $0 \cdot 1 \mathrm{mM}$ PMSF, $1 \%$ Triton-X 100, $0.5 \%$ deoxycholic acid, and $0.1 \%$ sodium dodecyl sulphate. After extensive washing with this buffer (5×5 minutes) IgG and IgM immune complexes were detected by incubating the blots for one hour with a horseradish peroxidase conjugated IgG fraction goat antihuman $\gamma$ chain specific or $\mu$ chain specific serum (Cappel Labs, Cochransville, PA), diluted $1: 500$ or $1: 200$ in $0.5 \%$ bovine serum albumin phosphate buffered saline, $0.5 \%$ Triton-X 100. After five additional washes the immunostain reaction was visualised with diaminobenzidine and $\mathrm{H}_{2} \mathrm{O}_{2}$ as the substrate. A kit of seven coloured protein standards (Amersham-Rainbow marker) was used to determine molecular weights ranging from 200 kilodaltons (myosin) to 14.3 kilodaltons (lysozyme). Anti-Scl-70 antibody was identified as an immunostain reaction at 92 kilodaltons and compared with an anti-Scl-70 reference serum.

\section{STATISTICAL ANALYSIS}

$\chi^{2}$ Tests, with or without Yates's correction for small groups, Student's $t$ test for paired groups, and Fisher's exact test were performed.

\section{Results}

Table 1 shows the demographic characteristics of the 
994 Aeschlimann, Meyer, Bourgeois, et al

patients with CREST, PSS, and overlap syndrome. Ten of $64(16 \%)$ patients were male. The patients with CREST were significantly older than those with overlap syndrome $(p<0.05)$. The mean duration of disease was significantly longer in patients with CREST than in patients with PSS type III $(p<0.02)$ and patients with overlap syndrome $(p<0 \cdot 05)$.

Antinuclear antibodies as determined by indirect immunofluorescence on rat liver sections were present in the sera of $44 / 64(69 \%)$ patients. The most common pattern was homogeneous 23/44 $(52 \%)$, followed by a speckled $15 / 44(34 \%)$ and a nucleolar pattern $6 / 44$ (14\%).

With $\mathrm{HEp}_{2}$ cells as substrate antinuclear antibodies were detected in $47 / 64(73 \%)$ patients' sera. Eight of 11 serum samples from patients with CREST were negative on liver sections, seven of these nine showed a speckled pattern on $\mathrm{HEp}_{2}$ cells characteristic of anticentromere antibodies (Table 2). A comparison of antinuclear antibodies detected on rat liver sections and on $\mathrm{HEp}_{2}$ cells showed a similar pattern in $31 / 64(48 \%)$ cases. Antinuclear antibodies were detected in eight cases exclusively on liver section, in seven cases exclusively on $\mathrm{HEp}_{2}$ cells, and in either one or the other test in 55/64 $(86 \%)$ patients.

Anticentromere antibodies were found in nine $(82 \%)$ of the 11 patients with CREST and in two of

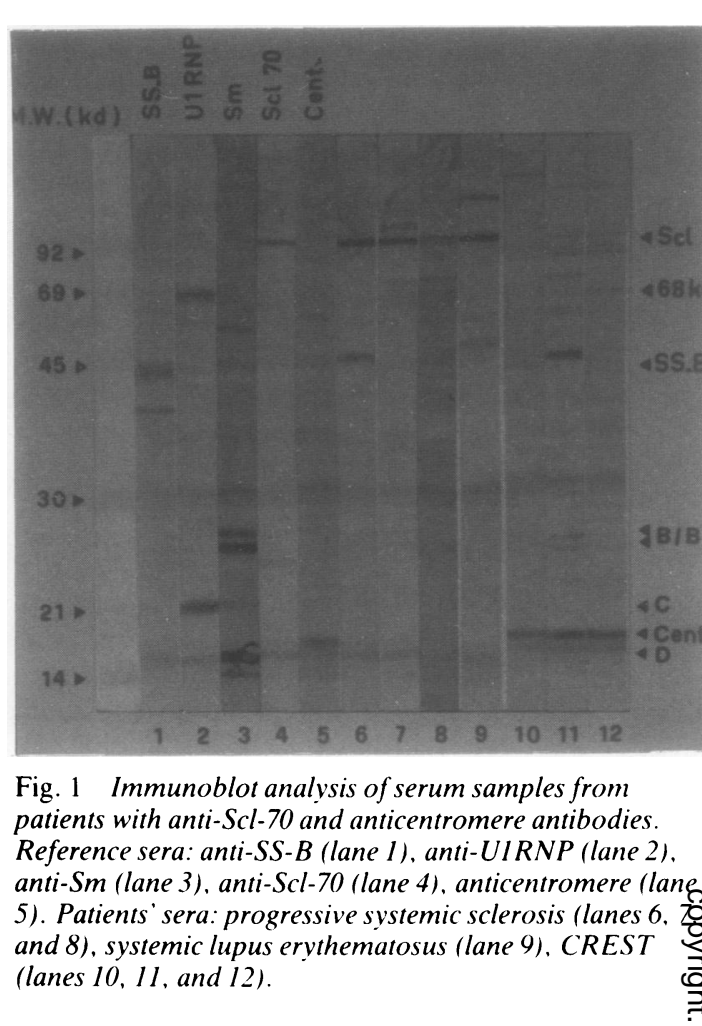

Table 1 Demographic characteristics of the patients with systemic sclerosis $(n=64)$

\begin{tabular}{|c|c|c|c|c|c|}
\hline & \multirow{2}{*}{$\begin{array}{l}\text { CREST } \\
(n=11)\end{array}$} & \multicolumn{3}{|l|}{ PSS* } & \multirow{2}{*}{$\begin{array}{l}\text { Overlap } \\
\text { syndrome } \\
\text { in }=181\end{array}$} \\
\hline & & $\begin{array}{l}I \\
(n=15)\end{array}$ & $\begin{array}{l}I I \\
(n=1.3)\end{array}$ & $\begin{array}{l}I I I \\
(n=7)\end{array}$ & \\
\hline Sex ratio $(M / F)$ & $0 / 11$ & $3 / 12$ & $1 / 12$ & $3 / 4$ & $3 / 15$ \\
\hline $\begin{array}{l}\text { Mean (SD) age (years) } \\
\text { (Range) }\end{array}$ & $\begin{array}{l}66 \cdot 4(10) \\
(36-75)\end{array}$ & $\begin{array}{l}59 \cdot 4(15 \cdot 3) \\
(15-75)\end{array}$ & $\begin{array}{l}54 \cdot 2(11 \cdot 3) \\
(22-65)\end{array}$ & $\begin{array}{l}48 \cdot 4(18 \cdot 4) \\
(2+68)\end{array}$ & $\begin{array}{l}48 \cdot 4(13 \cdot 6) \\
(22-68)\end{array}$ \\
\hline $\begin{array}{l}\text { Mean (SD) disease duration (years) } \\
\text { (Range) }\end{array}$ & $\begin{array}{l}25 \cdot 9(16 \cdot 9) \\
(1-52)\end{array}$ & $\begin{array}{l}15 \cdot 3(16 \cdot 1) \\
(1-49)\end{array}$ & $\begin{array}{l}11 \cdot 0(7 \cdot 4) \\
(1-31)\end{array}$ & $\begin{array}{l}6 \cdot 7 \quad(6) \\
(1-16)\end{array}$ & $\begin{array}{l}13 \cdot 4(10 \cdot 0) \\
(1-27)\end{array}$ \\
\hline
\end{tabular}

${ }^{*}$ PSS $=$ progressive systemic sclerosis.

Mean age: CREST $v$ overlap syndrome: $p<0 \cdot 05$.

Mean disease duration: CREST $v$ type III PSS: $p<0.02$ : CREST $v$ overlap syndrome: $p<0.05$.

Table 2 Prevalence of antinuclear antibodies on rat liver sections and $\mathrm{HEp} p_{2}$ cells and of anticentromere antibodies inㅡㅡㅁ various subtypes of systemic sclerosis. Values show number $(\%)$ of patients

\begin{tabular}{|c|c|c|c|c|c|c|}
\hline & \multirow{2}{*}{$\begin{array}{l}\text { CREST } \\
(n=I 1)\end{array}$} & \multicolumn{3}{|l|}{$\mathrm{PSS}^{+}$} & \multirow{2}{*}{$\begin{array}{l}\text { Overlap } \\
\text { sindrome } \\
\text { (n=18) }\end{array}$} & \multirow{2}{*}{$\begin{array}{l}\text { Total } \\
(n=6+1)\end{array}$} \\
\hline & & $\begin{array}{l}\text { Type I } \\
(n=15)\end{array}$ & $\begin{array}{l}\text { Type II } \\
(n=1.3)\end{array}$ & $\begin{array}{l}\text { Type } I I I \\
(n=7)\end{array}$ & & \\
\hline ANAt (liver section) & $3(27)$ & $9(60)$ & $10(77)$ & $7(100)$ & $15(83)$ & $+4(69)$ \\
\hline ANA $\left(\mathrm{HEp}_{2}\right.$ cells $)$ & $9(82)$ & $10(67)$ & $10(77)$ & $+(57)$ & $14(78)$ & $+7(73)$ \\
\hline Anticentromere antibodies & $9(82)^{*}$ & & $1(8)$ & & $1(6)$ & $11(17)$ \\
\hline \multicolumn{7}{|c|}{$\begin{array}{l}{ }^{*} \mathrm{p}<0.000001\left(\chi^{2}=26\right) \text { CREST } v \text { PSS. } \\
+\mathrm{PSS}=\text { progressive systemic sclerosis: ANA = antinuclear antibodies. }\end{array}$} \\
\hline
\end{tabular}


Table 3 Prevalence of serum anti-Scl-70 antibody (anti-Scl-70) detected with immunodiffusion and immunoblotting in 64 patients with systemic sclerosis. Values show number (\%) of patients

\begin{tabular}{llllr}
\hline & $\begin{array}{l}\text { CREST } \\
(n=11)\end{array}$ & $\begin{array}{l}\text { PSS } \\
(n=35)\end{array}$ & $\begin{array}{l}\text { Overlap } \\
\text { syndrome } \\
(n=18)\end{array}$ & $\begin{array}{l}\text { Total } \\
(n=64)\end{array}$ \\
\hline $\begin{array}{l}\text { Anti-Scl-70 detected with: } \\
\text { Immunodiffusion } \\
\text { Immunoblotting }\end{array}$ & 0 & $6(17)$ & 0 & 6 \\
\hline
\end{tabular}

${ }^{*}$ PSS = progressive systemic sclerosis.

the remaining patients, one with PSS type II and one with overlap syndrome (PSS associated with rheumatoid arthritis). With immunoblotting all the patients with anticentromere antibodies also showed the presence of autoantibodies against a 17 kilodalton antigen (Fig. 1).

With immunodiffusion, anti-Scl-70 antibodies were detected in $6 / 64(9 \%)$ PSS sera. None of the controls (SLE, MCTD, healthy blood donors) was positive. Anti-Scl-70 antibodies were not detected in sera from patients with the CREST variant or with

Table 4 Prevalence of serum anti-Scl-70 antibody (anti-Scl-70) detected with immunodiffusion and immunoblotting in 145 sera from patients with connective tissue disease and in 30 sera from healthy blood donors. Values show number (\%) of patients

\begin{tabular}{|c|c|c|c|c|}
\hline & $\begin{array}{l}\text { Systemic } \\
\text { sclerosis } \\
(n=64)\end{array}$ & $\begin{array}{l}S L E^{*} \\
(n=55)\end{array}$ & $\begin{array}{l}M C T D^{*} \\
(n=26)\end{array}$ & $\begin{array}{l}H B D^{*} \\
(n=30)\end{array}$ \\
\hline \multicolumn{5}{|c|}{ Anti-Scl-70 detected with: } \\
\hline Immunodiffusion & $6 \quad(9)$ & $\mathbf{0}$ & 0 & 0 \\
\hline Immunoblotting & $31(48)$ & $6(11)$ & $2(8)$ & 0 \\
\hline
\end{tabular}

*SLE=systemic lupus erythematosus; $\mathrm{MCTD}=$ mixed connective tissue disease: $\mathrm{HBD}=$ healthy blood donors. the overlap syndrome. All patients with anti-Scl-70 antibodies detected by immunodiffusion were also positive for anti-Scl-70 antibodies on immunoblotting.

With immunoblotting $31 / 64(48 \%)$ sera were positive for an anti-Scl-70 protein antibody also recognised by the anti-Scl-70 reference serum. When only patients with PSS types I to III were considered anti-Scl-70 were detected with immunodiffusion in $6 / 35(17 \%)$ sera and with immunoblotting in $22 / 35(63 \%)$ sera (Table 3$)\left(\chi^{2}=15 \cdot 2, p<0.0001\right)$. Anti-Scl-70 antibodies were also found in $6 / 55(11 \%)$ patients with SLE, in 2/26 $(8 \%)$ patients with MCTD, and in none of 30 healthy blood donors (Table 4). As calculated from our data the anti-Scl-70 antibody detected with immunoblotting has a specificity of $93 \%$ for PSS.

As judged by the clinical features associated with anti-Scl-70 antibodies or anticentromere antibodies, the duration of the disease was significantly shorter in patients with anti-Scl-70 antibodies than in those without $(p<0.02)$, the mean age was similar in both groups. The two groups did not differ from each other for any other clinical (Table 5) or biological features such as erythrocyte sedimentation rate, rheumatoid factor, serum immunoglobulin concentrations, anti-tissue antibodies.

Table 5 Characteristics of 31 anti-Scl-70 antibody positive patients and 33 anti-Scl-70 antibody negative patients with systemic sclerosis. Values show number (\%) of patients

\begin{tabular}{lcc}
\hline & $\begin{array}{l}\text { Anti-Scl-70 } \\
p r e s e n t \\
(n=31)\end{array}$ & $\begin{array}{l}\text { Anti-Scl-70 } \\
\text { absent } \\
(n=33)\end{array}$ \\
\hline Mean (SD) age (years) & $54 \cdot 4(12 \cdot 6)$ & $52 \cdot 2(15)$ \\
Mean (SD) disease duration (years) & $11 \cdot 5(9 \cdot 5)$ & $17 \cdot 6(15 \cdot 6)$ \\
Calcinosis & $7(23)$ & $15(45)$ \\
Telangiectasia & $14(45)$ & $19(58)$ \\
Digital pitting ulcers & $12(39)$ & $15(45)$ \\
Arthritis & $16(52)$ & $10(30)$ \\
Myositis & $10(32)$ & $7(21)$ \\
Lung fibrosis & $18(58)$ & $16(48)$ \\
Cardiac involvement & $5(16)$ & $5(15)$ \\
Oesophageal dysfunction & $19(61)$ & NS \\
Renal involvement & $3(10)$ & NS \\
NS & NS \\
\hline
\end{tabular}


996 Aeschlimann, Meyer, Bourgeois, et al

\section{Discussion}

Detection of antinuclear antibodies in 44/64 (69\%) of the cases using rat liver section and $47 / 64(73 \%)$ using $\mathrm{HEp}_{2}$ cells as substrate is comparable with previously published data. ${ }^{19}{ }^{20}$. Recently, Giordano et al reported that antinuclear antibodies with a diffusely grainy and nucleolar pattern associated with anti-Scl-70 antibodies were significantly more prevalent in a form of PSS they called 'diffuse cutaneous systemic sclerosis', ${ }^{21}$ which was characterised by poor prognosis. This finding has not been confirmed by other authors. ${ }^{22}$ In our series the different fluorescent nuclear patterns did not correlate with the severity of the disease.

An $82 \%$ prevalence of anticentromere antibodies in patients with the CREST variant as compared with a $4 \%$ prevalence in patients with PSS or with overlap syndrome confirms the diagnostic value of this autoantibody for the CREST variant of PSS. The prevalence of anticentromere antibodies in patients with CREST has been estimated as between $55 \%$ and $96 \% .{ }^{46} 23$

Similar results were recently published by Rothfield et al using cloned autoantigen CENP-B for enzyme linked immunosorbent assay (ELISA) detection of anticentromere antibodies. ${ }^{24}$

According to other authors, patients with the CREST variant are characterised by a significantly longer mean duration of disease and less involvement of internal organs. ${ }^{25}{ }^{26}$ Weiner et al did not find that patients with scleroderma with anticentromere antibodies had a longer disease duration nor that these antibodies identify patients with less severe disease. ${ }^{23}$ When the mean age at diagnosis is considered the patients with anticentromere antibodies are significantly older than those without. We suggest that variability of serological and clinical characteristics is the consequence of differences in selection and classification of patients. ${ }^{15}$

With immunoblotting anti-Scl-70 were found in $31 / 64(48 \%)$ patients with PSS, in $6 / 55(11 \%)$ patients with SLE, in $2 / 26(8 \%)$ patients with MCTD, and in none of 30 healthy blood donors. The data resulted in a specificity of $93 \%$ of this antibody in systemic sclerosis. Anti-Scl-70 antibodies are therefore not absolutely specific for PSS as they are also found in SLE and MCTD. It is possible that reactions with unidentified intracellular peptides with the same molecular weight as Scl-70 have been identified and it is not certain that all the antibodies are truly against Scl-70. The sensitivity of anti-Scl-70 antibody detected by immunoblotting $(48 \%)$ is significantly higher than that reported in previous studies using immunodiffusion as standard detection technique. ${ }^{\$ 5}$ In those studies
anti-Scl-70 antibodies were detected in up to $20 \%$ of cases.

Our study showed that the specificity of anti-Scl70 for PSS is lower by immunoblotting than immunodiffusion $(93 \% v 100 \%$ in our series). Theo information contained in both tests is comple- $\bar{O}$ mentary as the source of antigen is not the same. $\frac{\bar{\sigma}}{\bar{s}}$ Immunodiffusion is fast and reliable. With immuno- $\frac{\mathrm{D}}{\mathrm{a}}$ blotting it is possible to obtain more precise information about the different antigenic components ${ }^{\infty}$ and, in addition, to detect several other specificities. $\stackrel{\circ}{\circ}$ The prevalence of anti-Scl-70 in the different sub- $\vec{\omega}$ groups was $18 \%$ in the CREST syndrome, $39 \%$ in scleroderma associated with overlap syndrome, and $63 \%$ in types I-III of diffuse scleroderma. These? results re-emphasise the diagnostic value of this $\propto$ antibody, which seems able to discriminate between $\vec{\sim}$ subsets of systemic sclerosis-for example, PSS and $\&$ the CREST variant. This was first suggested by Tan N et al. ${ }^{4}$ Comparable results have been published by을 Weiner $e t$ al, who found that anti-topoisomerase $\mathrm{I}-$ was positive in $26 \%$ of patients who fulfilled the ARA criteria for systemic sclerosis and in $10 \%$ of patients with four clinical features of the CREST 3 syndrome. ${ }^{23}$ With immunoblotting Van Venrooij@ et al detected the presence of autoantibodies againgt $\vec{t}$ an 86000 mol.wt marker antigen in 13/22 (59\%) patients with diffuse scleroderma and in only $1 /$ f1. (9\%) patients with limited scleroderma. ${ }^{7}$.

The presence of anti-Scl-70 antibody in patients with diffuse scleroderma according to the Barnetto and Coventry classification does not correlate with the severity of the disease. Our data do not support $\stackrel{\mathbb{}}{\Omega}$ the conclusion previously published that anti-Scl- $70 \overrightarrow{0}$ antibodies are associated with skin ulcerations and 3 cardiac $^{23}$ or lung involvement. ${ }^{27} 28$ On the other? hand, duration of disease was significantly shorter in patients with anti-Scl-70 antibodies than in those without. This suggests that screening for anti-Scl-70을 antibody with immunoblotting is particularly useful 3 in the early stages of the disease. Whether the presence of anti-Scl-70 antibody has any prognostic value so far as severity and progression of disease are concerned will have to be confirmed by prospec-음 tive longitudinal studies.

We would like to thank the Swiss Rheumatology Society for financial support. The anti-Scl-70 reference serum was a gift from Dr Humbel. Centre Hospitalier, Luxembourg.

\section{References}

1 Le Roy E C. Krieg T. Black C. et al. Scleroderma (systemic sclerosis): classification, subsets and pathogenesis. $J$ Rheumatoke 1988: 15: 202-5

2 Douvas A S. Achten M. Tan E M. Identification of a nuclear $\mathscr{S}$ protein (Scl-70) as a unique target of human antinuclear antibodies in scleroderma. J Biol Chem 1979; 254; 10514-22.

3 Shero J. Bordwell B. Rothfield N F. Earnshaw W C. High titers 
of autoantibodies to topoisomerase I (Scl-70) in sera from scleroderma patients. Science 1986; 231: 737-40.

4 Tan E M, Rodnan G P, Garcia I, Moroi Y, Fritzler M J, Peebles C. Diversity of antinuclear antibodies in progressive systemic sclerosis. Anti-centromere antibody and its relationship to CREST syndrome. Arthritis Rheum 1980; 23: 617-25.

5 Catoggio L J, Skinner R P, Maddison P J. Frequency and clinical significance of anticentromere and anti-Scl-70 antibodies in an English connective tissue disease population. Rheumatol Int 1983; 3: 19-23.

6 Fritzler M J, Kinsella T D, Garbutt E. The CREST syndrome: a distinct serologic entity with anticentromere antibodies. $A m J$ Med 1980; 69: 520-6.

7 Van Venrooij W J, Stapel S O, Houben H, et al. Scl-86, a marker antigen for diffuse scleroderma. $J$ Clin Invest 1985; 75: 1053-60.

8 Bernstein R M, Steigerwald J C, Tan E M. Association of antinuclear and antinucleolar antibodies in progressive systemic sclerosis. Clin Exp Immunol 1982; 48: 43-51.

9 Powell F C, Weinelmann R K, Venencie-Lemarchand F, Spurbeck J L, Schroeter A L. The anticentromere antibody: disease specificity and clinical significance. Mayo Clin Proc 1984; 59: 700-6.

10 Towbin H, Staehelin T, Gordon J. Electrophoretic transfer to proteins from polyacrylamide gels to nitrocellulose sheets: procedure and some applications. Proc Natl Acad Sci USA 1979; 76: 4350-4.

11 Barnett A J, Coventry D A. Scleroderma: clinical features, course of illness and response to treatment in 61 cases. Med J Aust 1969; 1: 992-1101.

12 Subcommittee for scleroderma criteria of the American Rheumatism Association diagnostic and therapeutic criteria committee. Preliminary criteria for the classification of systemic sclerosis (scleroderma). Arthritis Rheum 1980; 23: 581-90.

13 Tan E M, Cohen A S, Fries J F, et al. The 1982 revised criteria for the classification of systemic lupus erythematosus. Arthritis Rheum 1982; 25: 1271-7.

14 Alarcon-Segovia D. Classification and diagnostic criteria for mixed connective tissue disease. In: Kasukawa R, Sharp G C, eds. Mixed connective tissue disease and antinuclear antibodies. Amsterdam: Elsevier, 1987: 33-40.

15 Miller M H, Littlejohn G O, Jones B W, Strnad H. Clinical comparison of cultured human epithelial cells and rat liver as substrates for the fluorescent antinuclear antibody test. J Rheumatol 1985; 12: 265-9.
16 Ouchterlony O, Nilsson L A. Immunodiffusion and immunoelectrophoresis. In: Weir D M ed. Handbook of experimental immunology. London: Blackwell Scientific, 1978: 19.1-44.

17 Habets W H, De Rooij D J, Salden M H, et al. Antibodies against distinct nuclear matrix proteins are characteristic for mixed connective tissue disease. Clin Exp Immunol 1983; 54: 265-76.

18 Laemmli U K. Cleavage of structural proteins during the assembly of the head of bacteriophage T4. Nature 1979; 227: 680-5.

19 Jordan R E, Deheet D, Schroeter A, et al. Antinuclear antibodies: the significance in scleroderma. Mayo Clin Proc 1971; 46: 111-3.

20 Riboldi $\mathrm{P}$, Asero R, Origgi S, et al. Antinuclear antibodies in progressive systemic sclerosis. Clin Exp Rheumatol 1985; 3: 205-11.

21 Giordano M, Valentini G, Migliaresi S, Picillo U, Vatti M. Different antibody patterns and different prognoses in patients with scleroderma with various extent of skin sclerosis. J Rheumatol 1986; 13: 911-6.

22 Burgos-Vargas B, Martinez-Cordero E, Reyes-Lopez P A, Herrera-Esparza R. Antibody pattern and other criteria for diagnosis and classification in PSS. $J$ Rheumatol 1988; 15: 153-4.

23 Weiner E S, Earnshaw W C, Senecal J L, Bordwell B, Johnson $P$, Rothfield N F. Clinical associations of anticentromere antibodies and antibodies to topoisomerase I. A study of 355 patients. Arthritis Rheum 1988; 31: 378-85.

24 Rothfield N, Whitaker D, Bordwell B, Weiner E, Senecal J L, Earnshaw W. Detection of anticentromere antibodies using cloned autoantigen CENP-B. Arthritis Rheum 1987; 30: 1416-9.

25 McCarty G A, Rice J R, Bembe M L, Barada F A. Anticentromere antibody. Clinical correlations and association with favorable prognosis in patients with scleroderma variants. Arthritis Rheum 1983; 26: 1-7.

26 Steen V D, Ziegler G L, Rodnan G P, Medsger T A. Clinical and laboratory associations of anticentromere antibody in patients with progressive systemic sclerosis. Arthritis Rheum 1984; 27: 125-31.

27 Catoggio L J, Bernstein R M, Black C M, Hughes G R V, Maddison $\mathbf{P}$ J. Serological markers in progressive systemic sclerosis: clinical correlations. Ann Rheum Dis 1983; 42: 23-7.

28 Steen V D, Powell D L, Medsger T A. Clinical correlations and prognosis based on serum autoantibodies in patients with systemic sclerosis. Arthritis Rheum 1988; 31: 196-203. 